Scientia Marina 71(2)

June 2007, 259-267, Barcelona (Spain)

ISSN: 0214-8358

\title{
Low crested coastal defence structures on the Catalan coast of the Mediterranean Sea: how they compare with natural rocky shores
}

\author{
ESPERANÇA GACIA, MARIA PAOLA SATTA and DANIEL MARTIN \\ Centre d'Estudis Avançats de Blanes-CSIC. Ctra. Accés Cala Sant Francesc 14, 17300 Blanes. \\ E-mail: gacia@ceab.csic.es
}

\begin{abstract}
SUMARY: Erosion problems in coastal zones are increasingly threatening Mediterranean shores. In tourist areas such as the Catalan coast, there has been an increasing demand for the construction of low crested structures (LCS) to maintain beaches for recreational purposes. We studied the composition of the biota from three LCS and compared it with that of nearby natural rocky shores. Our purpose was to assess the composition of the communities growing on the LCS at a regional scale and to explore potential patterns of community composition in LCS in relation to the nature of the surrounding coast (i.e. sand or rocky shore), distance from natural hard-bottom communities and orientation of the blocks within the structure. The communities growing on the LCS were similar to those from nearby natural shores but the diversity and the number of taxa was always lower. Sixty to $95 \%$ of the species present on natural rocky shores grew on LCS, and differences in the number of taxa between the natural and the artificial substrates increased with increasing distances between them. On the Catalan coast, LCS act as impoverished rocky shores that never become natural 'climax' communities.
\end{abstract}

Keywords: Mediterranean, low-crested coastal defence structures, epibiota, community composition.

RESUMEN: ESTRUCTURAS DE BAJA COTA (EBC) PARA LA DEFENSA COSTERA EN EL LITORAL CATALÁN: COMPOSICIÓN DE LAS COMUNIDADES Y COMPARACIÓN CON LOS FONDOS ROCOSOS NATURALES. - La afectación por problemas de erosión de la costa Mediterránea ha aumentado significativamente en las últimos tiempos. Zonas turísticas como la costa Catalana, han experimentado una demanda creciente de construcción de Estructuras de Baja Cota (EBC) para la defensa costera con el fin de estabilizar la arena en playas de uso recreativo. Estudiamos la composición de los epibiontes en tres sistemas de EBC, comparándola con la de comunidades rocosas naturales cercanas a los EBC. El objetivo es analizar dicha composición a escala regional, así como determinar la posible existencia de patrones en relación con el tipo de costa que rodea las estructuras (arena o rocas), la distancia a la costa rocosa natural y la orientación de los bloques de cada estructura. Las comunidades que crecen en los EBC son parecidas a las de la roca natural, aunque siempre tienden a presentar una menor diversidad y riqueza específica. Las especies presentes en los EBC representan entre un $60 \%$ y un $95 \%$ de las de la roca natural, mientras que las diferencias en el número de taxones entre ambos sustratos aumenta a medida que lo hace la distancia que los separa. En la costa catalana, los EBC funcionan como un sustrato rocoso pobre en especies, donde nunca se llega a alcanzar la composición de las comunidades clímax características de la zona.

Palabras clave: Mediterráneo, estructuras de baja cota, epibiota, composición de las comunidades.

\section{INTRODUCTION}

Mediterranean coastal areas are threatened by coastal development that modifies the coastline through the construction of buildings and infrastructures such as roads, railways, promenades and ports. The main consequences of this development are changes in the deposition processes and wave regime that lead to increasing erosion. In addition, the sea-level rise and increasing storminess due to climate change may also contribute to beach recession and flooding in coastal areas.

Along the Catalan coast, beach tourism is one of the main resources of the local economy, and there has 
been an increasing demand to obtain land and stability on the coastline. The construction of coastal defence structures to protect beaches from erosion and even to help to maintain artificially nourished beaches has significantly increased during the last few decades. The most common local forms of these constructions are jetties and, most recently, offshore breakwaters (i.e. low-crested structures [LCS]) with or without groins.

LCS are structures parallel to the shore that can be submerged or regularly overtopped by waves (Lamberti et al., 2005). On the Catalan coast, LCS are formed by single units protecting small beaches or systems formed by several units plus, in some cases, groins. Their presence has direct consequences on the hydrodynamics of the coastal cell, and on the sediment transport and composition (i.e. granulometry and organic content; Martin et al., 2005). Since the nature and structure of soft-bottom assemblages is directly related to sediment descriptors (Gray, 1974), significant changes in the infaunal communities are expected after the construction of sea defences. Indeed, a broad scale comparison of soft-bottom assemblages associated with LCS structures along with the Atlantic, Adriatic and western Mediterranean European coasts, under very different hydrodynamic regimes (i.e. macro, micro and a-tidal shores) and coast types indicated shifts in the structure and function of the infaunal communities after the construction of LCS. Compared with reference sites, deposit feeders tended to increase (in parallel with an organic enrichment of sediments) on the landward side of the structures, while suspension feeders increased on the exposed side following an increase in the coarse fraction of sediments (Martin et al., 2005).

As for biota, LCS represent a new rocky habitat for colonisation that modifies the natural limits of rocky shores (Moschella et al., 2005). The communities growing on seawalls (i.e. sea-defences, harbours) are similar to those from natural rocky shores but in essence a poor imitation (Moschella et al., 2005). The common structure of sea defences based on blocks creates strong gradients of exposure resulting in a patchy community composition of the biota (e.g. Glasby and Connell, 2001). Moreover, the structural design of the LCS can be modified to influence cover and species composition (Moschella et al., 2005) according to the particular ecology of the area. LCS may also facilitate the spread of invasive species that encounter a new colonisation substrate (Airoldi et al., 2005) and thus potentially compete with the native biota.
In this study we explore patterns of community composition on LCS compared with natural rocky shores, representing different structures along the Catalan coast. Differences from the European regional study (see Moschella et al., 2005) are expected when small local detail is considered, taking into account the particularities of this shoreline without tides that alternates from rocky to sandy beaches. Indeed, LCS impact processes do not scale up or down (Airoldi et al., 2005) and the environmental consequences of a construction very much depend on the ecological context, local characteristics and background knowledge (Airoldi et al., 2005).

We here analyse what grows on several LCS structures compared with the nearest rocky communities. We stress the differentiation of habitat (seaward vs landward) and the effect of single structures (i.e. formed by a single barrier) vs more complex structures (i.e. formed by several barriers) resulting from the LCS construction (see Fig. 1). We also consider patterns related to the distance between natural and artificial substrates, and the importance of the habitat surrounding the LCS (i.e. sand or rocks) for community composition. The final goal is to provide informative data to managers on how we expect the biota to evolve following the apparently inevitable construction of LCS on Mediterranean coasts.

\section{METHODS}

\section{Study sites and sampling design}

The study was conducted within the framework of the project 'Environmental Design of Low Crested Coastal Defence Structures' (DELOS; EVK3 200022038). Three sites with a different number of LCS units were studied (see Fig. 1 and details in Table 1).

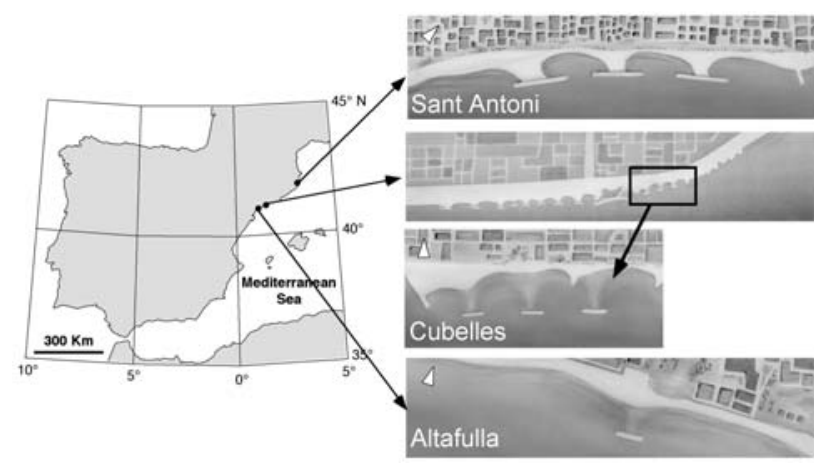

FIG. 1. - Location and aerial photographs of the areas of study on the Catalan coast. Black arrows indicate N. 
TABLE 1. - Descriptors of the three LCS structures studied.

\begin{tabular}{|c|c|c|c|}
\hline Feature of LCS & Altafulla & Cubelles & Sant Antoni \\
\hline $\begin{array}{l}\text { Latitude } \\
\text { Longitude } \\
\text { Number of LCS } \\
\text { Groins } \\
\text { Height mid-shore above sed. seaw. (m) } \\
\text { Height mid-shore above sed. land. (m) } \\
\text { Date of construction } \\
\text { Length at sea bed (LSB) } \\
\text { Length at crest level (LCL) } \\
\text { Initial distance from shore } \\
\text { Average size gaps (m) } \\
\text { Material used (type and rugosity) } \\
\text { Shape of blocks } \\
\text { Adjacent structures } \\
\text { Beach nourishment events } \\
\text { Nearest distance to nat. rock (m) } \\
\text { Composition of the nat. rock. } \\
\text { Others }\end{array}$ & $\begin{array}{c}41^{\circ} 7{ }^{\prime} 53 \text { ', } \mathrm{N} \\
1^{\circ} 22^{\prime} 18, ' \mathrm{E} \\
1 \\
\text { No } \\
3.5-4.5 \\
3 \\
1991 \\
116 \\
100 \\
180 \\
\pm 0.3 \\
\text { granite } \\
\text { cubes of quarry rock } \\
\text { No } \\
\text { Yes, regularly } \\
500 \\
\text { calcareous }\end{array}$ & $\begin{array}{c}41^{\circ} 11^{\prime} 48^{\prime}, \mathrm{N} \\
1^{\circ} 40{ }^{\prime}, \mathrm{E} \\
3 \\
\text { No } \\
3.5 \\
2.1-2.6 \\
1992 \\
130 \\
115 \\
160 \\
\text { granite } \\
\text { cubes of quarry rock } \\
\text { Yes } \\
\text { Yes, regularly } \\
1500 \\
\text { calcareous } \\
\text { Adjacent structures } \\
\text { Thermal power plant }\end{array}$ & $\begin{array}{c}41^{\circ} 50 ’ 49, \\
3^{\circ} 6 \text { '29', } \\
3 \\
\text { Yes } \\
4 \\
0.5-1 \\
1981-86-98 \\
170 \\
155 \\
\\
\text { granite } \\
\text { cubes of quarry rock } \\
\text { Yes } \\
\text { Yes, regularly } \\
800 \\
\text { granite } \\
\text { Adjacent structures }\end{array}$ \\
\hline
\end{tabular}

In all cases the structures were parallel to the shoreline, emerged 1 to $2 \mathrm{~m}$ above sea level and were situated 50 to $200 \mathrm{~m}$ from the coastline. On this coast, tides are not significant and the LCS are emerged except during occasional storm events, when all three structures can be overtopped by the waves. The structures are located on the Catalan coast: Altafulla (Costa Daurada) with a single structure, Cubelles (Costa Daurada) with three LCS closed by two lateral jetties and Sant Antoni de Calonge (Costa Brava) with three LCS with groins, also closed by jetties (Fig. 1). The three LCS structures were constructed (or reworked) more than ten years ago to prevent beach erosion. The beaches are regularly nourished to supplement the action of the LCS. For each structure, we selected the nearest natural rocky shore as a reference area to compare the composition of the biota with that of the LCS.

The cover and diversity of epibiont species was studied in the upper infralittoral zone (i.e. the zone characterised by alternation of emersion and submersion; see Guidetti et al., 2004). The biota was studied in late spring and summer from 2001 to 2003. Visual inventories were conducted from outside the water when the water was backing down due to the small wave movement. Two scientists estimated independently the cover (as a percentage of area occupied) of all macroscopic species in a 25 x $25 \mathrm{~cm}$ quadrat subdivided into 25 subquadrats. The percent cover was quantified by giving each individual taxon a score ranking from presence (less than 5\%) to $25 \%, 50 \%, 75 \%$ and $100 \%$ cover in each small quadrat, and then adding up the scores of all the smaller quadrats. This method has proved to give consistent estimates when compared with other, more robust techniques, particularly in areas with high hydrodynamics and low disturbances such as the ones studied here (e.g. Sala and Ballesteros, 1997; Cebrián et al., 2000). The species were either identified in situ or taken to the laboratory for further classification. A single data matrix was kept from the field data.

Four randomly distributed points with three replicated quadrats per point were sampled in three different situations for each LCS: 1) exposed side (seaward), 2) sheltered side (landward), and 3) within blocks (only in Altafulla). In the reference areas, we used the same sampling design but only the exposed side of the natural rocks was available for study.

\section{Statistical analysis}

The total number of species (S), the percentage area covered $(\mathrm{N})$ and the Shannon-Wiener diversity index $\left(\mathrm{H}^{\prime}\right)$ were obtained for each sample and analysed by means of a between-groups (sites) and exposure (orientation) ANOVA design, and a between-groups (sites) and nature of the coast (LCS or natural rock) design (Statistica software). We had three sites (Altafulla, Cubelles and Calonge) with three levels each: reference site (R), seaward side (S) and landward side (L). Each level had twelve replicates. Post hoc multiple comparisons were done by the Tukey HSD test (Sokal and Rohlf, 1995). All data were tested for normality and homoscedasticity prior to statistical analysis. 
The patterns of distribution of the communities were explored and graphically represented using multi-dimensional scaling (MDS) and the BrayCurtis similarity index (Clarke and Warwick, 1994). Significance tests for differences among locations and sites were performed using the analysis of similarities (ANOSIM), whereas the similarity percentage procedure (SIMPER) was employed to identify the contribution of each species to dissimilarities (Clarke, 1993; Clarke and Warwick, 1994). Data were square root transformed and standardised prior to multivariate statistical analysis.

\section{RESULTS}

The composition of the natural communities differed significantly among the three sites (Fig. 2), thus indicating regional differences, particularly between the northern (Sant Antoni) and the two southern stations (Altafulla and Cubelles) (Table 2a.). The main differences were the following: The cover of Corallina elongata Ellis and Solander was very high in the south and low in Sant Antoni, whereas Cystoseira mediterranea Sauvageau showed the opposite pattern (Figs. 3a, b). There was a high cover of Mytilus galloprovincialis Lam. in Cubelles (Fig. $3 c)$. In Altafulla, there were also two samples with $C$. mediterranea, as seen by the two outliers closer to the Sant Antoni stations (Fig. 3). Sant Antoni showed the highest number of species and diversity (Fig. 4a, b), while Cubelles and Altafulla had similar numbers of species, with the diversity being particularly low in Altafulla (Fig. 4b). The total cover of the biota was similar in the three reference sites (Fig. 4c).

The composition of the biota was significantly different between natural and LCS substrates, including the different orientation of the structures (landward and seaward; Fig. 5; Table 2b.). Corallina elongata was the most abundant species at all sites and in all orientations (Fig. 6a), contributing to $80 \%$ of the similarity in the LCS assemblages. The highest dissimilarity was found between the reference points and the landward side of the structure $(64 \%)$, followed by the reference points and the seaward side (57\%) and finally the dissimilarity within the structure $(53 \%)$.

The different cover of Corallina elongata and Mytilus galloprovincialis explained the differences between the assemblages in the natural rock and

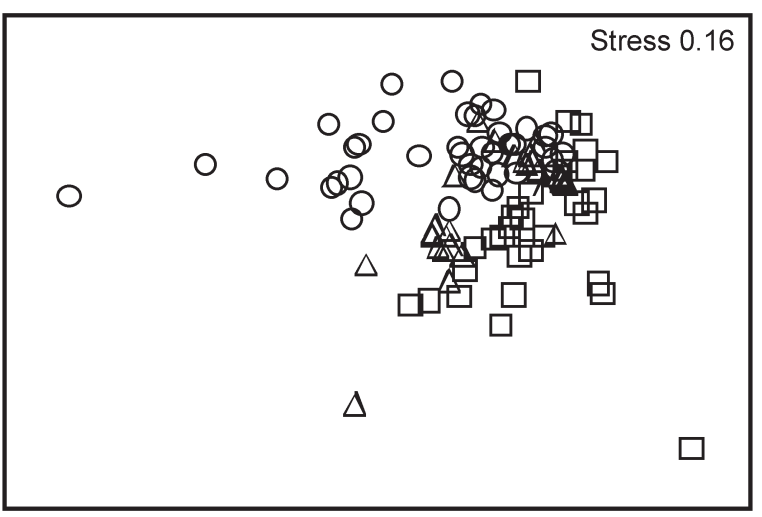

FIG. 2. - MDS plot for the biota from natural rocky shores on three sites. Triangles are for Sant Antoni de Calonge, squares for Cubelles and circles for Altafulla. Differences between groups were tested using ANOSIM (global R=0.579; $\mathrm{p}<0.001$ ).
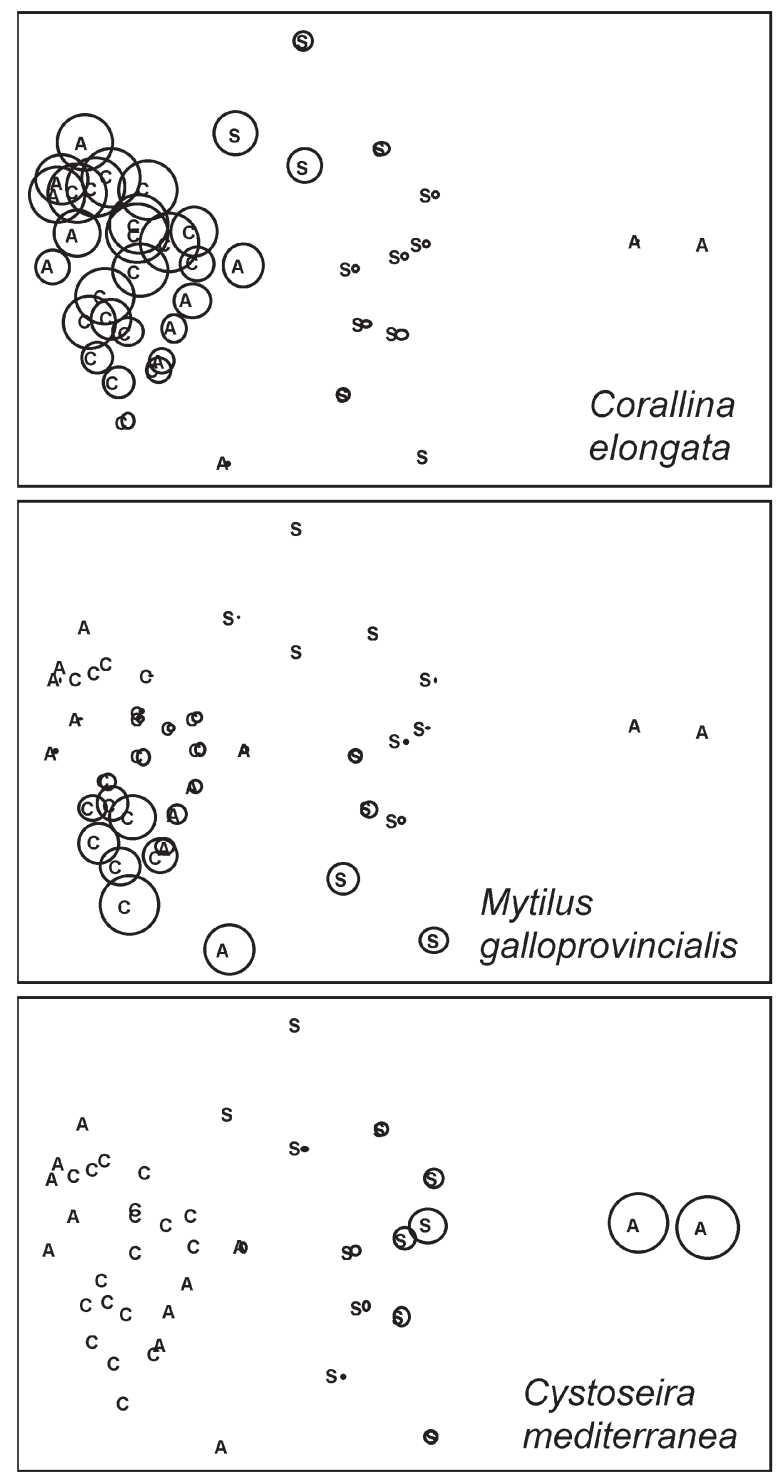

FIG. 3. - Bubble graphs showing the main species responsible for the regional differences in the composition of the hard-substrate communities along the Catalan coast. SA: Sant Antoni de Calonge; C: Cubelles; A: Altafulla. Stress: 0.12. 


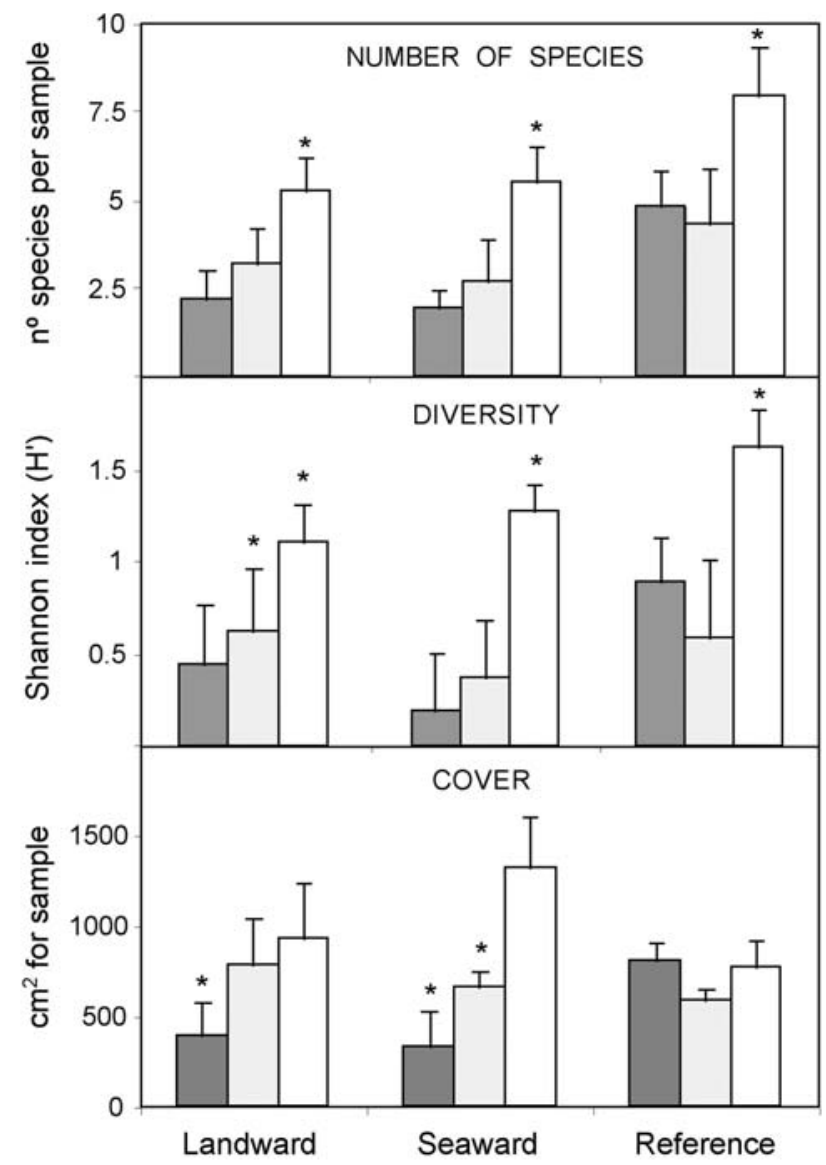

FIG. 4. - Differences in number of species (a), diversity (b) and cover (c) in the composition of the biota between reference sites and orientations of LCS blocks. White bars: Sant Antoni de Calonge; grey bars: Cubelles; dotted bars: Altafulla; * indicates significant differences $(\mathrm{p}<0.01)$ between sites within treatments.

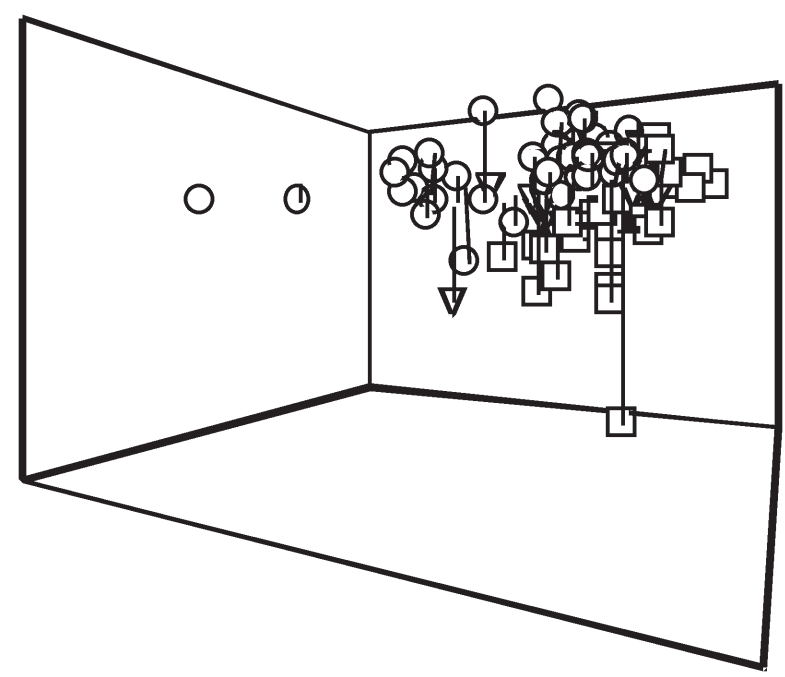

FIG. 5. - MDS showing the differences in the composition of the biota between natural, LCS substrates, and orientations (landward and seaward). Circles are for reference sites; triangles are for LCSseaward; squares are for LCS-landward. Differences between groups tested using ANOSIM (global R =0.468; $\mathrm{p}<0.01$ ).
TABLE 2. - Results of the two-way crossed ANOSIM with significant differences for the factor 'Region' (global R =0.579; $\mathrm{p}<0.001$ ) with levels $\mathrm{S}=$ Sant Antoni, $\mathrm{C}=$ Cubelles and $\mathrm{A}=$ Altafulla; and 'Nature of the substrate' (global $\mathrm{R}=0.468 ; \mathrm{p}<0.001$ ) with levels $\mathrm{R}$ $=$ reference, $\mathrm{L}=$ landward, $\mathrm{S}=$ seaward. Data were square root transformed and standardised.

Region

\begin{tabular}{lll}
\hline Groups & Statistic & Level \% \\
C, A & 0.339 & 0.1 \\
C, SA & 0.786 & 0.1 \\
A, SA & 0.702 & 0.1 \\
Nature of the substrate & & \\
\hline & & \\
Groups & & \\
L, S & Statistic & 0.1 \\
L, R & 0.363 & 0.1 \\
S, R & 0.643 & 0.1 \\
\hline
\end{tabular}

those on the exposed side of the structure. Within the LCS, the high cover of Litophyllum incrustants Philippi at the exposed site (Fig. 6b) and the low cover in the absence of $M$. galloprovincialis (Fig. $6 c)$ on the landward side of the LCS were mainly responsible for the differences observed.

The number of taxa was always significantly higher in the natural substrate than on the LCS (Fig. 4a; ANOVA $\mathrm{p}>0.001$ ), the latter including between 60 and $95 \%$ of the taxa present at the reference sites. The diversity was also significantly higher on the natural shores than on the LCS except on the landward side of the structure in Altafulla, where it was similar to the that of the reference site (Fig. 4b). The cover, however, did not show any significant pattern according to the orientation (Fig. $4 \mathrm{c})$. The number of structures and the presence of groins did not seem to have any effect on the LCS's community parameters since Altafulla (1 structure) showed an intermediate number of species, diversity and cover compared with the other localities (3 structures; Figs. 4a, b, c).

Differences in the number of species between the natural and the artificial substrates increased proportionally to the distance between the two systems (Fig. 7).

\section{DISCUSSION}

Regional differences in the hard-bottom assemblages were more important than the nature of the substrate (i.e. natural vs coastal defences) in the composition of the epibiota of the three systems 

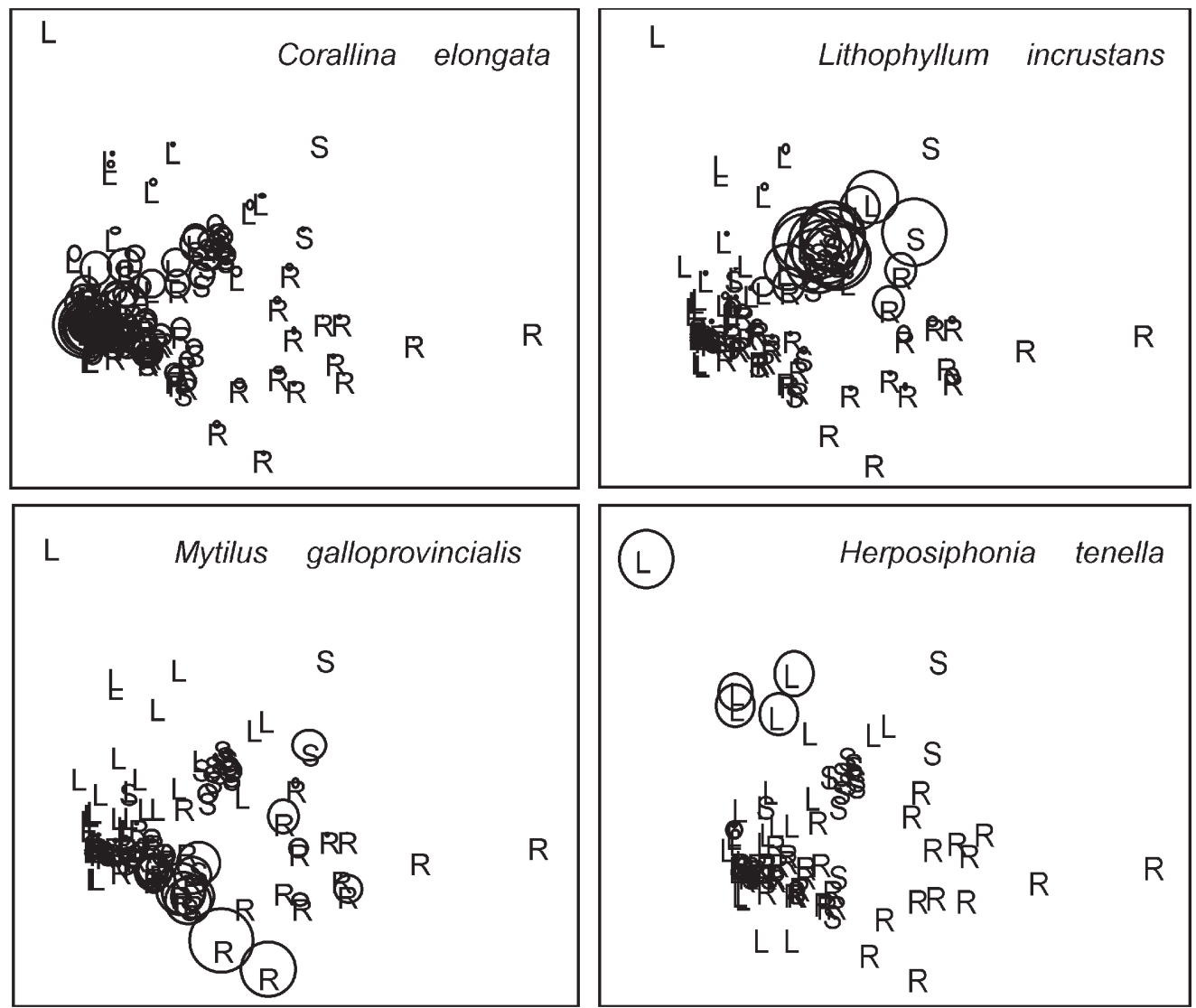

FIG. 6. - Bubble graphs showing the main species responsible for the differences in the MDS ordination between natural and LCS substrates. Stress: 0.15 .

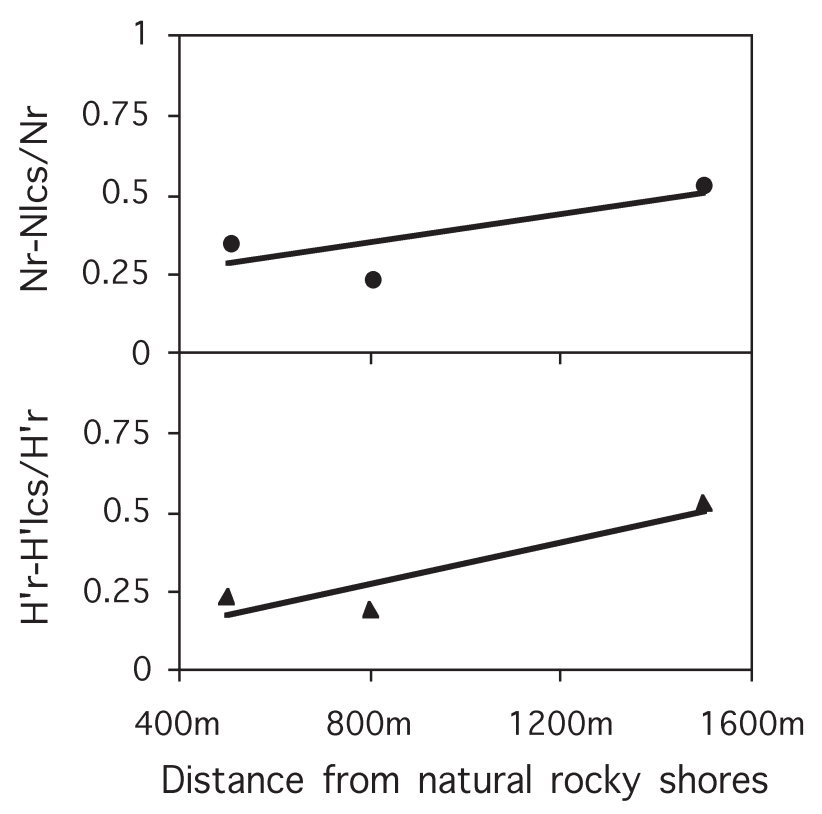

FIG. 7. - Differences in number of species (N) and Shannon diversity index (H') between the exposed site of the LCS (lcs) and their respective reference sites $(\mathrm{r})$ at each sampling station, in relation $\mathrm{t}$ o their distance in metres. studied. The main regional differences encountered were in agreement with the pattern of community composition in relation to water quality all along the Catalan coast described by Ballesteros et al. (1984) and reassessed in Pinedo et al. (2006). At the northern station, the reference sites are characterised by the dominance of communities typical of high water quality (i.e. dominance of Cystoseira mediterranea), while in the south, the reference communities indicate a stronger human influence (i.e. dominance of the Corallina elongata turf). This shift in community composition indicates some degree of eutrophication (i.e. presence of rivers and ports). Within the two southern stations, the high cover of Mytilus galloprovinciallis in Cubelles compared with Altafulla also reflects an even lower water quality at the former station.

The different mineral composition of the reference sites does not seem to have an effect on the composition of the epibiota. Studies showing the importance of biomineralogy in the structuring of sessile benthic communities show how quartz-rich substrates hold less diverse and mature communi- 
ties than limestone coasts (i.e. Bavestrello et al., 2000), contrary to the patterns observed in this study. Thus, water quality seams to be the major factor driving the structure and composition of the epibiota on the Catalan coast for both natural or artificial substrates.

The results from this study also confirm previous reports of intrinsic differences between natural and artificial rocky shores (i.e. Bulleri, 2005; Ballesteros et al., 2006), even for these three LCS structures that had been colonised for over 10 years, which is close to the time for the development of a 'normal' hard-substrate community (Hawkins et al., 1983). Indeed, the species present on the studied LCS are later colonisers (i.e. Moschella et al., 2005), indicating maturity in the artificial assemblages. The main differences between the natural and the artificial assemblages are a lower number of species and diversity in the artificial substrates and a significantly different community composition. These patterns may be due to a less diverse substrate-surface on the lowcrested defence compared to the natural rocks (see Fletcher and Callow, 1992 for a review). The presence of different scales of crevices and pools creates more diverse microhabitats that can potentially be colonised by a number of species with a different autoecology (Metaxas and Scheibling, 1993; Russell, 1999). Indeed, experimental manipulation of artificial substrates towards increasing micro-crevices and fractures, and also increasing the presence of rock pools, resulted in an increase in the number of species and diversity on the artificial substrate (Moschella et al., 2005).

The main species responsible for the differences between the natural and the artificial substrate were the high cover of Corallina elongata on the artificial substrate, and the opposite pattern of Miytilus galloprovincialis, which was particularly rare on the landward side of the LCS (Figs. 3a, c). C. elongata is the most common species on the Catalan coast when water quality is good to acceptable (i.e. Pinedo et al., 2006), and it extends all over the Cystoseira mediterranea zone when the latter disappears (Ballesteros et al., 1984; Thibaut et al., 2005). On the artificial substrates studied here, the presence of C. elongata indicates some stabilisation of the substrate, since the turf was well developed and several centimetres wide, and this species needs several years to expand (growing rates for Corallina sp. of $1.4 \mathrm{~mm} \mathrm{month}{ }^{-1}$; Andrake and Johansen, 1980).
Moreover, a frequent rebuild and perturbation of boulders in LCS generates more immature communities dominated by fast-growing ephemeral algae together with Mytilus sp. (Bacchiocchi and Airoldi, 2003). The high cover of Corallina sp. on the LCS is probably solely a consequence of a low diversity of the community on the artificial substrate.

The proliferation of Mytilus galloprovincialis on artificial substrates is a common phenomenon that has already been described in different seas [e.g. Ballesteros et al. (2006) in the Mediterranean, Bacchiocchi and Airoldi (2003) in the Adriatic, Glasby and Connell (2001) in Australia]. M. galloprovincialis are particularly abundant on the exposed sides of the structures, while they may become rare on the sheltered sides either because of confinement (Burcharth, 1993), or because people collect the mussels for recreational purposes (Bacchiocchi and Airoldi, 2003). In Cubelles, we also observed an extremely high sediment deposition on the sheltered side of the structure (Gacia, unpublished data), which caused the presence of a fine film of silt covering the assemblages on the landward side. We thus hypothesise that the lack of M. galloprovincialis on the landward side in Cubelles may be due to the high level of confinement of the shallow landward blocks causing a suffocation of the filtration system of the bivalve (Dare, 1976). Indeed, M. galloprovincialis is very abundant on the Catalan coast in polluted and perturbed areas (such as ports, the Ebro Delta and coastal constructions in general) but it also indicates high hydrodynamics (Pinedo et al., 2006), which explains why it is so abundant on the exposed side of the structures.

A recent extensive investigation on intertidal hard-bottom assemblages from the Catalan coast shows that the quality descriptors used for natural assemblages cannot be applied to artificial blocks (Ballesteros et al., 2006). Indeed, Cystoseira mediterranea, the algae characteristic of pristine intertidal communities, never occurs on artificial blocks, even if they are more than several decades old. Thus, taking into consideration our results, we can conclude that the community encountered on the exposed side of the different structures can be considered the 'climax' of the hard-bottom assemblages growing on artificial substrate. It is important to recall that the management of the structure will very much determine the succession of communities from artificial blocks (i.e. 
Burchard and Lamberti, 2005), and that periodical rebuilding should shift succession processes in the biota, causing a substitution of this 'mature' community towards communities dominated by fast-growing ephemeral algae (Moschella et al., 2005; Bulleri, 2005), the latter potentially causing an accumulation of algal debris on the sheltered shores and thus decreasing the quality of the coastal waters.

In this study, the number of structures in the LCS system does not appear to have a significant influence on the composition of the associated hard-bottom communities. This is probably due to the proximity of natural rocks to the structures, which ensures the arrival of propagules to the different LCS elements. However, there was an inverse relationship between the number of species in the LCS communities and the distance between the LCS and natural rocky shores (see Fig. 7). Although this pattern should be further explored, it indicates the importance of natural rocky shore assemblages to nourish the artificial substrates with propagules and guarantee a development of their communities similar to the natural ones.

We show here how the presence of natural rocks near the artificial sea defences minimises the differences between the communities growing on the natural substrates and the ones growing on the artificial ones. This is totally opposite to what occurs on other coasts such as the Adriatic, where the presence of large extensions (hundreds of kilometres) of artificial structures in areas without natural rock may transform the hard-bottom assemblages into corridors for invasive species and/or cause a decrease in the genetic separation between the native populations (Airoldi et al., 2005).

In summary, the impact of a coastal construction should be regarded from a coastal cell perspective, since major changes in sediment transport and softbottom assemblages have been shown and the composition of the new assemblages growing on hard substrates will depend on the nature and characteristics of the nearby coast. Moreover, in addition to the focus of coastal managers on hydrodynamic and sediment morphodynamic issues in the planning of coastal constructions, they should always pay special attention to analysing the biotic patterns and dynamics at a regional scale, always avoiding overconstruction and major transformations that may cause significant perturbations in the functioning of our coasts.

\section{ACKNOWLEDGEMENTS:}

We are grateful to all our DELOS partners for stimulating discussions and learning processes. This work was funded under the European Community DELOS project (Contract: $\mathrm{n}^{\circ}$ EVK3-CT-200000041). We thank S. Hawkins and an anonymous referee for significantly improving the final version of the ms.

\section{REFERENCES}

Airoldi, L., M. Abbiati, M.W. Beck, S.J. Hawkins, P.R. Jonsson, D. Martin, P. Moschella, A. Sundelöf, R.C. Thompson and P. Åberg. - 2005. An ecological perspective on the deployment and design of low-crested and other hard coastal defence structures. Coast. Eng., 52(10-11): 1073-1087.

Andrake, W. and H.W. Johansen. - 1980. Alizarin red dye as a marker for measuring growth in Corallina officinalis L. (Corallinaceae, Rhodophyta). J. Phycol., 16: 620-622.

Arévalo, R., S. Pinedo and E. Ballesteros. - 2006. Changes in the composition and structure of Mediterranean rocky-shore communities following a gradient of sewage pollution: descriptive study and test of proposed methods to assess water quality regarding macroalgae. Mar. Pollut. Bull. In press

Bacchiocchi, F. and L. Airoldi. - 2003. Distribution and dynamics of epibiota on hard structures for coastal protection. Est. Coast. Shelf Sci., 56: 1157-1166.

Ballesteros, E., M. Pérez and M. Zabala. - 1984. Aproximación al conocimiento de las comunidades algales de la zona infralitoral superior en la costa catalana. Collect. Bot. 15: 69-100.

Ballesteros, E. and S. Pinedo. - 2000. Metodología de las comunidades bentónicas (bentos). Agència Catalana de l'Aigua, Generalitat de Catalunya; Consejo Superior de Investigaciones Cientificas (CSIC). INTERREG II C.

Ballesteros, E., X. Torras, S. Pinedo, M. García, L. Mangialajo and M. de Torres. - 2007. A new methodology based on littoral community cartography for the implementation of the European Water Framework Directive. Mar. Pollut. Bull., 55: 172-180.

Bavestrello, G., C.N. Bianchi, B. Calcinai, R. Cattaneo-Vietti, C. Cerrano, C. Morri, S. Puce and M. Sarà. - 2000. Biomineralogy as a structuring factor for marine benthic communities. Mar. Ecol. Progr. Ser., 193: 241-249.

Bulleri, F. - 2005. Role of recruitment in causing differences between intertidal assemblages on seawalls and rocky shores. Mar. Ecol. Progr. Ser., 287: 53-65.

Burcharth, H.F. - 1993. The design of breakwaters. In: M.A. Abbott and V.A. Price (eds.), Coastal, estuarial and harbor engineer's reference book, pp. 381-424. Chapman and Hall, London.

Burcharth, H.F. and A. Lamberti. - 2005. Environmental Design Guideliness of Low Crested Coastal Defence Structures. Pitagora Editrice, Bologna.

Clarke, K.R. - 1993. Non-parametric multivariate analysis of changes in community structure. Aust. J. Ecol., 18: 117-143.

Clarke, K.R. and R.M. Warwick. - 1994. Change in marine communities: an approach to statistical analysis and interpretation. PRIMER-E ( $2^{\text {nd }}$ edition $)$, Plymouth.

Cebrián, E., E. Ballesteros and M. Canals. - 2000. Shallow rocky bottom benthic assemblages as calcium carbonate producers in the Alboran Sea (Southwestern Mediterranean). Oceanol. Acta, 23: 311-322.

Dare, P.J.-1976. Settlement, growth and production of the mussel, Mytilus edulis L., in Morecambe Bay, England. Fish. Invest. Minist. Agric. Fish. Food (G.B.) (2 Sea Fish). vol 28(1).

Fletcher, R.L. and M.E. Callow. - 1992. The settlement, attachment and stablishment of marine algal spores. Br. Phycol. J., 27: 303-329.

Glasby, T.M. and S.D. Connell. - 2001. Orientation and position of 
substrata have large effects on epibiotic assemblages. Mar. Ecol.Prog. Ser., 214: 127-135.

Gray, J.J. - 1974. Animal-sediment relationships. Oceanogr. Mar. Biol. Ann. Rev., 12: 223-261.

Guidetti, P., C.N. Bianchi, M. Chiantore, S. Schiaparelli, C. Morri and R. Cattaneo-Vietti. - 2004. Living on the rocks: Substrate mineralogy and the structure of subtidal rocky substrate communities in the Mediterranean Sea. Mar. Ecol. Prog. Ser., 274: 57-68.

Hawkins, S.J., A.J. Southward and R.L. Barrett. - 1983. Population structure of Patella vulgata L. during succession on rocky shores in Southwest England. Oceanol. Acta. Proceedings $17^{\text {th }}$ European Marine Biology Symposium: 103-107.

Lamberti, A., R. Archetti, M. Kramer, D. Paphitis, C. Mosso and M. Di Risio. - 2005. European experience of low crested structures for coastal management. Coast. Eng., 52(10-11): 841-866.

Martin, D., F. Bertasi, M. Colangelo, M. de Vries, M. Frost, S.J. Hawkins, E. Macpherson, P.S. Moschella, M.P. Satta, R.C. Thompson and V.U. Ceccherelli. - 2005. Ecological impact of coastal defence structures on sediment and mobile fauna: evaluating and forecasting the consequences of an unavoidable modification of the native habitats. Coast. Eng. 52(10-11): 1027-1051.

Metaxas, A. and R.E. Scheibling. - 1993. Community structure and organization of tidepools. Mar. Ecol.Prog. Ser., 98(1-2): 187-198.

Moschella P.S., M. Abbiati, P. Åberg, L. Airoldi, F. Bacchiocchi, F. Bulleri, G.E. Dinesen, M. Frost, E. Gacia, L. Granhag, P.R. Jonsson, M.P. Satta, A. Sundelöf, R.C. Thompson and S.J. Hawkins. - 2005. Low Crested Coastal Defence Structures as artificial habitats for marine life: what lives where and why? Coast. Eng., 52(10-11): 1053-1071.

Pinedo, S., M. García, M., P. Satta, M. de Torres and E. Ballesteros. - 2007. Rocky-shore communities as indicators of water quality: a case study in the Northwestern Mediterranean. Mar. Pollut. Bull., 55: 126-135.

Russell, G. - 1999. The algal vegetation of coastal defences: a case study from NW England. Bot. J. Scot., 52(1): 31-42.

Sala, E. and E. Ballesteros. - 1997. Partitioning of space and food resources by three fish of the genus Diplodus (Sparidae) in a Mediterranean rocky infralittoral ecosystem. Mar. Ecol. Progr. Ser., 152: 273-283.

Sokal, R.R. and F.J. Rolf. - 1981. Biometry. Freeman, San Francisco.

Thibaut, T., S. Pinedo, X. Torras and E. Ballesteros. - 2005. Longterm decline of the populations of Fucales (Cystoseira and Sargassum) in the Albères coast (Northwestern Mediterranean). Mar. Pollut. Bull. 50: 1472-1489.

Torras, X., S. Pinedo, M. García, L. Mangialajo and E. Ballesteros. -2003 . Assessment of coastal environmental quality based on littoral community cartography: methodological approach. In: UNEP-MAP-RAC/SPA (edit.), Proceedings of the Second Mediterranean Symposium on marine vegetation, Athens, $\mathrm{pp}$. 145-154. RAC-SPA, Tunis.

Scient. ed.: J. Garrabou.

Received February 22, 2006. Accepted January 22, 2007.

Published online May 21, 2007. 
